\title{
Gambaran histologik aorta kelinci yang diinduksi dengan lemak babi dan diberi ekstrak beras hitam
}

\author{
${ }^{1}$ Lendy S. F. Polii \\ ${ }^{2}$ Djon Wongkar \\ ${ }^{2}$ Sunny Wangko
${ }^{1}$ Kandidat Skripsi Fakultas Kedokteran Universitas Sam Ratulangi Manado
${ }^{2}$ Bagian Anatomi Histologi Fakultas Kedokteran Universitas Sam Ratulangi Manado
Email: lendypolii12268@yahoo.com

\begin{abstract}
Dyslipidemia is an abnormal lipid metabolism, marked by the alteration of lipid fractions within the blood plasma. World Health Organization reported that dyslipidemia was associated with heart diseases in general with 4 million deaths each year. Dyslipidemia is mostly caused by unhealthy lifestyle. The change of lifestyle can be initiated by the modification of diet. Black rice (Oryza sativa L.) is a type of local rice which contains a different pigment than the regular or any other colored rice. This study aimed to identify the histological changes of rabbit aorta induced with lard and black rice extract diet. This was an experimental study with a post-test design. Subjects were three rabbits New Zealand white divided into 3 groups (A. B. And C) of 1 rabbit each. Group A was fed with standard diet (Vitamax), group B with high fat diet, meanwhile group $\mathrm{C}$ was fed with high fat diet added with black rice extracts. This study was carried out for 28 days, after that all the rabbits were terminated to obtain their aortas. The results showed that there were reductions of LDL and total cholesterol levels of group C. Foam cells were found in the tunica intima and tunica media in group A, B and C. However, the foam cells in group C were less than the other groups. Conclusion: Black rice diet could reduce the LDL and total cholesterol levels as well as the number of foam cells in the aorta tunica of rabbits.
\end{abstract}

Keywords: aorta, rabbits, foam cells, black rice extracts, lard

\begin{abstract}
Abstrak: Dislipidemia adalah kelainan metabolisme lipid yang ditandai dengan peningkatan maupun penurunan fraksi lipid dalam plasma. WHO memperkirakan dislipidemia berhubungan dengan kasus penyakit jantung secara luas, serta menyebabkan empat juta kematian per tahun. Dislipidemia umumnya disebabkan karena gaya hidup. Perubahan gaya hidup dapat dilakukan mulai dari memodifikasi pola diet. Beras hitam (Oryza sativa L.) merupakan varietas lokal yang mengandung pigmen berbeda dengan beras putih atau beras berwarna lain. Penelitian ini bertujuan untuk mendapatkan gambaran histologik aorta kelinci yang diinduksi dengan lemak babi dan diberi pakan beras hitam. Jenis penelitian ini eksperimental dengan rancangan post test. Subyek penelitian kelinci New Zealand white dibagi menjadi tiga kelompok (A, B, dan C), masing-masing kelompok terdiri dari 1 kelinci. Kelompok A diberikan pakan standar (Vitamax), kelompok B diberikan diet tinggi lemak, dan kelompok C diberikan diet tinggi lemak serta ekstrak beras hitam. Perlakuan diberikan selama 28 hari dan selanjutnya dilakukan terminasi untuk mengambil aorta kelinci dan kemudian dianalisis. Hasil penelitian memperlihatkan penurunan kadar kolesterol LDL dan total pada kelompok C. Gambaran histologik aorta kelompok A, B dan C menunjukkan adanya sel-sel busa di lapisan tunika intima dan tunika media, namun jumlah sel busa di kelompok C lebih sedikit dari kelompok yang lain. Simpulan: Ekstrak beras hitam dapat menurunkan kadar kolesterol LDL dan total, serta jumlah sel busa di lapisan aorta pada kelinci.
\end{abstract}

Kata kunci: aorta, kelinci, sel busa, ekstrak beras hitam, lemak babi 
World Health Organization (WHO) menyatakan bahwa penyakit kardiovaskular merupakan penyebab kematian dan kecacatan diseluruh dunia. Setiap tahun diperkirakan 17,3 juta orang meninggal akibat penyakit kardiovaskular. Sebanyak 7,3 juta orang diantaranya terjadi akibat penyakit jantung dan 6,2 juta akibat stroke. Di Indonesia pada tahun 2012 penyakit jantung koroner (PJK) menduduki peringkat pertama yang menyumbangkan angka kematian. Angka kematian akibat kejadian penyakit kardiovaskukar semakin meningkat sebesar $37 \%$ penduduk. ${ }^{1}$

Hasil Riset Kesehatan Dasar (Riskesdas) tahun 2013 menjelaskan bahwa prevalensi penyakit kardiovaskular semakin meningkat seiring peningkatan umur. Prevalensi PJK secara keseluruhan sebesar 2\%. Provinsi Jawa Tengah menduduki peringkat ke empat secara keseluruhan sebesar 1,4\%. Di Sulawesi Utara sendiri, angka kejadian PJK sebesar 8,2\%. ${ }^{2}$

Salah satu faktor risiko PJK ialah dislipidemia. Dislipidemia adalah kelainan metabolisme lipid yang ditandai dengan peningkatan maupun penurunan fraksi lipid dalam plasma. WHO memperkirakan dislipidemia berhubungan dengan kasus penyakit jantung secara luas, serta menyebabkan empat juta kematian per tahun. ${ }^{3}$ Salah satu faktor yang perlu diperhatikan yakni dislipidemia seringkali tidak disertai gejala sehingga masyarakat kurang waspada akan bahayanya. Dislipidemia sebagian besar (80\%) disebabkan karena gaya hidup, sedangkan $20 \%$ disebabkan faktor genetik. ${ }^{3}$ Kolesterol low density lipoprotein (LDL) dan kolesterol total merupakan parameter yang menjadi fokus utama terapi dislipidemia, dimana keduanya masih dapat dimodifikasi dengan perubahan gaya hidup. ${ }^{4}$

Perubahan gaya hidup dapat dilakukan mulai dari memodifikasi pola diet. Beras hitam (Oryza sativa L.) merupakan varietas lokal yang mengandung pigmen berbeda dengan beras putih atau beras warna lain. ${ }^{4}$ Beras hitam memiliki perikarp, aleuron, dan endosperm yang berwarna merah-biruungu pekat. Warna tersebut menunjukkan adanya kandungan antosianin. Beras hitam mempunyai kandungan serat pangan dan hemiselulosa masing-masing sebesar 7,5\% dan 5,8\%,sedangkan beras putih hanya sebesar $5,4 \%$ dan $2,2 \%{ }^{5}$

\section{METODE PENELITIAN}

Jenis penelitian yaitu true experimental dengan menggunakan rancangan desain tunggal pre-test pada kelompok hewan percobaan kelinci (intact group). Subjek perlakuan pada penelitian ini ialah 3 ekor kelinci New Zealand white yang diberi kode $\mathrm{A}, \mathrm{B}$, dan $\mathrm{C}$, dengan kriteria inklusi yaitu: Hewan sehat dan berusia 3 bulan.

Sebelum penelitian, terlebih dahulu dilakukan adaptasi di dalam kandang kelinci selama 7 hari dengan suhu ruangan $24^{0} \mathrm{C}$, kemudian dilakukan pengambilan darah awal. Selanjutnya dimulai perlakuan terhadap 3 kelompok kelinci yaitu: kelompok A diberi pakan standar (Vitamax); kelompok B diet tinggi lemak; dan kelompok $\mathrm{C}$ diet tinggi lemak dengan ekstrak beras hitam. Perlakuan diberikan selama 28 hari dan setelah 28 hari dilakukan pengambilan darah untuk pemeriksaan kolesterol total dan LDL, lalu kelinci diterminasi. Aorta kelinci diambil, difiksasi dengan buffer formalin $10 \%$, lalu dibuat sediaan histologik.

\section{HASIL PENELITIAN DAN BAHASAN}

Tabel 1 dan 2 memperlihatkan hasil pemeriksaan kolesterol LDL dan total pada kelompok kelinci A, B, dan C.

Tabel 1. Hasil pemeriksaan kolesterol LDL

\begin{tabular}{ccccc}
\hline $\begin{array}{c}\text { Kelompo } \\
\text { k Kelinci }\end{array}$ & $\begin{array}{c}\text { Berat } \\
\text { Awal } \\
(\mathrm{kg})\end{array}$ & $\begin{array}{c}\text { Berat } \\
\text { Akhir } \\
(\mathrm{kg})\end{array}$ & $\begin{array}{c}\text { LDL } \\
\text { Awal } \\
(\mathrm{mg} / \mathrm{dL})\end{array}$ & $\begin{array}{c}\text { LDL } \\
\text { Akhir } \\
(\mathrm{mg} / \mathrm{dL})\end{array}$ \\
\hline A & 1,8 & 2,5 & 13 & 13 \\
$\mathrm{~B}$ & 2,2 & 3 & 4 & 118 \\
$\mathrm{C}$ & 2,3 & 2,9 & 11 & 9 \\
\hline
\end{tabular}

Tabel 2. Hasil pemeriksaan kolesterol total (KT)

\begin{tabular}{c|c|c|c|c}
\hline $\begin{array}{c}\text { Kelompok } \\
\text { Kelinci }\end{array}$ & $\begin{array}{c}\text { Berat } \\
\text { Awal } \\
(\mathrm{kg})\end{array}$ & $\begin{array}{c}\text { Berat } \\
\text { Akhir } \\
(\mathrm{kg})\end{array}$ & $\begin{array}{c}\text { KT } \\
\text { Awal } \\
(\mathrm{mg} / \mathrm{dL})\end{array}$ & $\begin{array}{c}\text { KT } \\
\text { Akhir } \\
(\mathrm{mg} / \mathrm{dL})\end{array}$ \\
\hline A & 1,8 & 2,5 & 58 & 49 \\
$\mathrm{~B}$ & 2,2 & 3 & 49 & 199 \\
$\mathrm{C}$ & 2,3 & 2,9 & 60 & 50 \\
\hline
\end{tabular}


Gambaran histologik aorta memperlihatkan sel busa pada tunika intima dan tunika media pada ketiga kelompok, namun terlihat lebih sedikit pada kelompok C (Gambar 1, 2, dan 3).

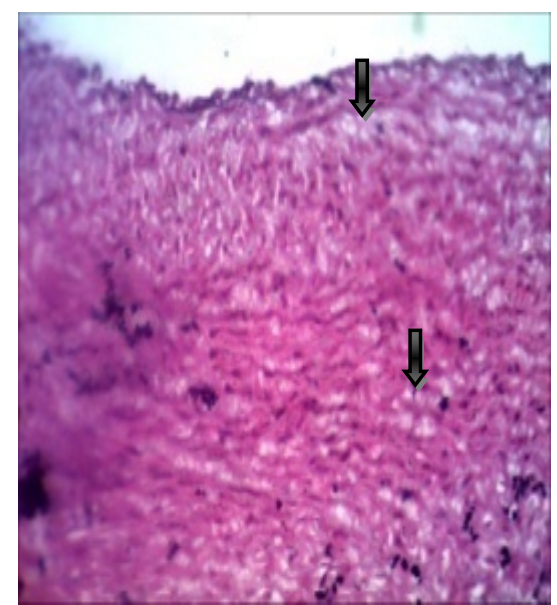

Gambar 1. Histologik aorta Kelompok A. Tampak adanya sel-sel busa (panah hitam).

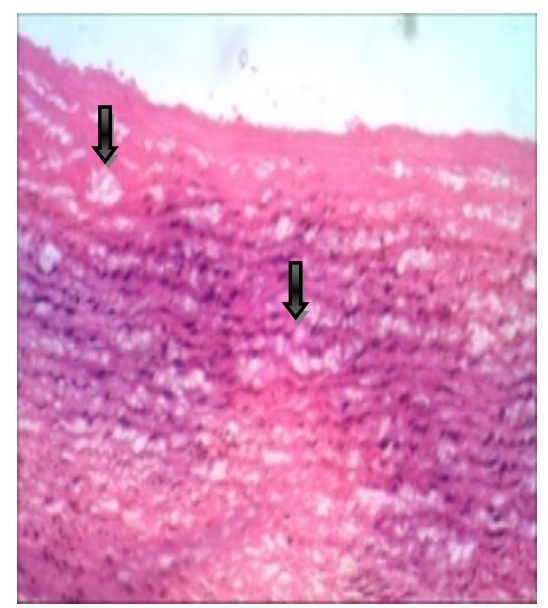

Gambar 2. Histologik Aorta Kelompok B. Tampak adanya sel-sel busa (panah hitam).

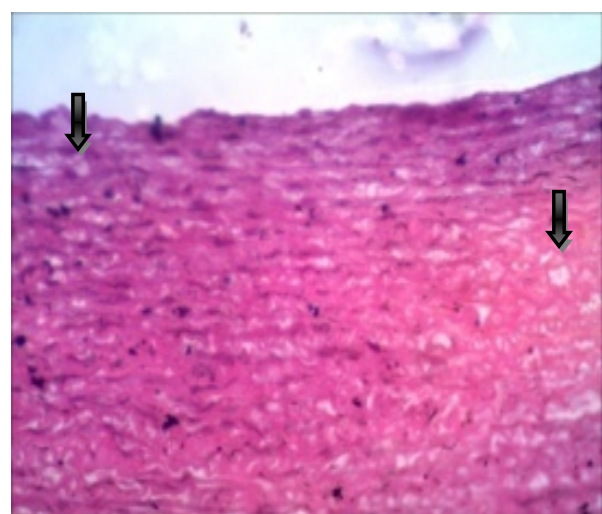

Gambar 3. Histologik aorta Kelompok C. Tampak adanya sel-sel busa (panah hitam).
Hasil pemeriksaan laboratorium kelinci kelompok A mendapatkan penurunan kadar kolesterol total sebesar $9 \mathrm{mg} / \mathrm{dL}$ tetapi tidak terjadi perubahan fraksi kolesterol LDL.

Pada kelinci kelompok B dengan perlakuan diet tinggi lemak terjadi peningkatan yang signifikan untuk kadar kolesterol LDL dan total. Kadar LDL kelinci meningkat dari $4 \mathrm{mg} / \mathrm{dL}$ menjadi $118 \mathrm{mg} / \mathrm{dL}$, sedangkan kadar kolesterol total meningkat dari $49 \mathrm{mg} / \mathrm{dL}$ menjadi 199 mg/dL (peningkatan 150 mg/dL)

Pada kelinci kelompok C, yaitu kelinci dengan diet tinggi lemak dan ekstrak beras hitam didapati adanya penurunan kadar kolesterol LDL dari $11 \mathrm{mg} / \mathrm{dL}$ menjadi 9 $\mathrm{mg} / \mathrm{dL}$ (penurunan $2 \mathrm{mg} / \mathrm{dL}$ ) sedangkan kadar kolesterol total dari $60 \mathrm{mg} / \mathrm{dL}$ menjadi $50 \mathrm{mg} / \mathrm{dL}$ (penurunan $10 \mathrm{mg} / \mathrm{dL}$ ).

Gambaran histologik aorta pada kelinci kelompok A terlihat banyak sel busa (Gambar 1) di tunika Intima dan tunika media. Hal ini mungkin disebabkan oleh komposisi yang terkandung dalam pakan standar yang mengandung lemak (2,5\%) sehingga terjadi peningkatan kolesterol LDL dalam darah.

Gambaran histologik aorta pada kelinci kelompok B terlihat banyak sel busa (Gambar 2). Hal ini disebabkan oleh pemberian diet lemak babi. Mengonsumsi lemak berlebihan menyebabkan hiperlipidemia dengan peningkatan koleseterol LDL. Hiperlipidemia kronis dapat mengganggu fungsi endotel melalui peningkatan radikal bebas oksigen yang mendeaktivasi nitrik oksida. Perubahan kimiawi lemak dipicu radikal bebas yang dihasilkan makrofag atau sel endotel pada dinding arteri akan menghasilkan LDL teroksidasi. LDL teroksidasi kemudian ditangkap oleh makrofag berubah menjadi sel busa. ${ }^{6,7}$

Gambaran histologik aorta pada kelinci kelompok $\mathrm{C}$ masih terlihat adanya sel busa (Gambar 3) walaupun lebih sedikit daripada kelompok B. Pemberian ekstrak beras hitam diharapkan dapat mencegah terbentuknya sel busa tetapi karena kelinci mengonsumsi lemak yang diberikan setiap hari dan pemberian ekstrak beras hitam 
yang masih kurang maksimal (28 hari), maka senyawa antosianin dalam ekstrak belum dapat memberikan efek optimal, sehingga masih terlihat adanya sel busa.

\section{SIMPULAN}

Dari hasil penelitian dan bahasan dapat disimpulkan bahwa ekstrak beras hitam dapat menurunkan kadar kolesterol LDL dan total, serta jumlah sel busa pada kelinci.

\section{UCAPAN TERIMA KASIH}

Ucapan terima kasih disampaikan kepada dr. Shane. H. R. Ticoalu M.Kes AIFO, dr. George Tanudjaja MS, PA(K) serta semua pihak yang baik secara langsung maupun tidak langsung telah menumbuhkan ide atau gagasan dalam pemikiran penulis.

\section{DAFTAR PUSTAKA}
1. World Health Organization, Noncomunicable Diseases Country Profiles, 2014.

2. Badan Penelitian dan Pengembangan
Kesehatan Kementerian Kesehatan RI. Riset Kesehatan Dasar, 2013.

3. Smith DG. Epidemiology of dyslipidemia and economic on the health care system. Am J Manag. 2007;13:S6871.

4. Imas R, Supriyatna, Subedjo, Keragaman warna gabah dan warna beras varietas lokal pada beras hitam yang dibudidayakan oleh petani di Kabupaten Sleman. Jurnal Vegetalika. 2013;3:13-20.

5. Hatma RD. Lipid profiles among diverse ethnic group in Indonesia. Acta Med Indones-Indones J Intern Med 2011;43(1):4-11.

6. Hermanto S, Muawanah A, Wardhani P. Analisis tingkat kerusakan lemak nabati dan lemak hewani akibat proses pemanasan. Jurnal Valensi. 2010;1(6):5-8.

7. Lamanepa MEL. Perbandingan profil lipid serum dan perkembangan lesi aterosklerotik pada tikus Wistar yang diberi diet perasan pare dengan diet perasan pare dan statin [Tesis]. Semarang: Universitas Diponegoro; 2006. 